\section{Polyfunctional TEM cells in psoriatic arthritis synovium skewed towards Th17 cells}

We read the article by Wade et $a l^{1}$ with great interest. With very elegant experiments, they have reported enrichment of polyfunctional T-lymphocytes in the synovial tissue of psoriatic arthritis (PsA); they have also noticed that polyfunctional synovial T-cells were positively associated with Disease Activity Index for Psoriatic Arthritis. We agree there are only limited studies in human autoimmune diseases which have addressed regulatory role of T-cell polyfunctionality of the activated effector memory $\mathrm{T}$ cells (TEM) in single cell suspensions. We have been working on TEM cell subpopulations in PsA and over years have demonstrated Th17, Th9 and mucosal-associated invariant $\mathrm{T}$ cells in $\mathrm{PsA}^{2-4}$ which are also polyfunctional. In respect to studying polyfunctional $\mathrm{T}$ cells in PsA instead of focusing on Th1, Th17 and exTh17 cells, ${ }^{1}$ we took a different approach to look into the cytokine profile and polyclonality of these TEM cells in respect their profound role in the disease process of PsA such as (IL-17, IL-23R, IL-22 and $\mathrm{TNF} \alpha$ ) and also compared with that polyfunctional T cells of rheumatoid arthritis (RA) to see whether a role of polyfunctional $\mathrm{T}$ cells can be reproduced in an another autoimmune arthritis and if so to identify the differences in degree/quality of the TEM polyfunctional cells at single cell level in these two different autoimmune arthritis.

We have studied synovial fluid $\mathrm{T}$ cells compared with the synovial tissue extracted $\mathrm{T}$ cells by Wade et al. ${ }^{1}$ Here, we are sharing our data which substantiates regulatory role of synovial polyfunctional T-cells in PsA as reported by Wade et al; further, it indicates that despite being polyfunctional (IL-17A+, IL- $22+$, TNF $\alpha+$, IFN $\gamma+$ ), the key pathological TEM cells in the inflamed joints of PsA are skewed towards Th17 cells joints compared with that of RA.

From untreated age/sex matched, patients with PsA and RA ( $n=15 /$ each) with active disease peripheral blood mononuclear cells (PBMC) and synovial fluid mononuclear cells (SFMC) were collected. $\mathrm{CD}^{+} \mathrm{T}$ cells were magnetically sorted and isolated from SFMCs and PBMCs. Isolated CD3 ${ }^{+}$ $\mathrm{T}$ cells $\left(10^{6}\right.$ cells $\left./ \mathrm{mL}\right)$ were activated with antihuman CD3/ CD28 cocktail; cells were cultured in the RPMI medium for 5 days (figure 1). Hi-D FACS studies were done (i) to identify activated memory $\left(\mathrm{CD} 11 \mathrm{a}^{+} \mathrm{CD} 45 \mathrm{RO}^{+}\right) \mathrm{T}$ cells $\left(\mathrm{CD} 3{ }^{+} \mathrm{CD} 4^{+} /\right.$ $\mathrm{CD} 8^{+}$) and (ii) to evaluate relevant Th1/Th17 cytokine profile: TNF $\alpha$, IFN $\gamma$, IL-17A, IL-22. Mean fluorescence intensity and the percentages of each cell population were analysed using a Flow Jo software. Experiments were carried-out in triplicates; results are described as Mean \pm SEM. One-way analysis of variance with Tukey multiple comparison test was used to compare results among more than two groups; $\mathrm{p} \leq 0.05$ was considered statistically significant.

Both in PsA and RA, marked polyfunctionality was noticed in T cells of PBMC/SFMC. However, compared with the matched blood $\mathrm{T}$ cell cytokine, polyfunctionality was more evident in the synovial cells. In PsA SFMCs, the numbers for IL-23R $(8.5 \% \pm 1 \%)$, IL-17A (15.5\% $1.4 \%)$ and IL-22 (8.4\% $1.3 \%)$ secreting cells were significantly higher $(\mathrm{p}<0.001)$ than the PsA PBMCs $(1.2 \% \pm 0.7 \%, 3.8 \% \pm 0.3 \%$ and $1.1 \% \pm 0.5 \%$, respectively), whereas in PsA, the \% of TNF $\alpha \mathrm{T}$ cells in PBMCs $(20.7 \pm 0.66)$ was more than PsA SFMCs $(8.16 \pm 0.11$, $\mathrm{p}<0.001)$; IFN $\gamma$ secreting cells in SFMCs and PBMCs were 3\% and $6 \%$, respectively. SFMCs of RA (figure 1) had significantly higher numbers $(\mathrm{p}<0.001)$ of IL-23R $(2.1 \% \pm 0.4 \%)$, IL-17A $(5.9 \% \pm 1.2 \%)$, IL-22 $(2.5 \% \pm 0.5 \%)$, TNF $\alpha(24.3 \% \pm 0.2 \%)$ secreting cells compared with RA PBMCs $(1.0 \% \pm 0.5 \%$, $1.8 \% \pm 0.1 \%, 0.8 \% \pm 0.2 \%$ and $14.3 \% \pm 0.2 \%$, respectively). PBMCs of RA had more numbers of IFN $\gamma$ producing cells $(\mathrm{p}<0.001)$ than SFMCs of RA $(15.8 \% \pm 0.5 \%$ vs $8.6 \pm 0.2 \%)$.

Consistent to report by Wade et $a l^{1}$ and our earlier reports, we noticed that activated CD4 memory $\mathrm{T}$ cells ${ }^{3}{ }^{4}$ were the major source for the lesional cytokines. More intriguing result is that both in RA and PsA the localised pathological TEM in the inflamed synovial fluid were vastly polyfunctional. However, though both in RA and PsA the key TEM cells in the synovium were polyfunctional, they were different and unique in their cytokine profile: (i) compared with RA (figure 1), the TEM cells in PsA SFMCs were skewed towards Th17 cells and this is likely because of higher expression of IL-23R in TEM cells of PsA; (ii) in RA, TEM cells were skewed towards Th1 cytokine profile; (iii) probably, this explains superior efficacy for anti-IL-17A targeted therapies in PsA compared with that of RA.

Our study demonstrates that despite the TEM cells are being polyfunctional at the single cell level still in PsA, the TEM cells
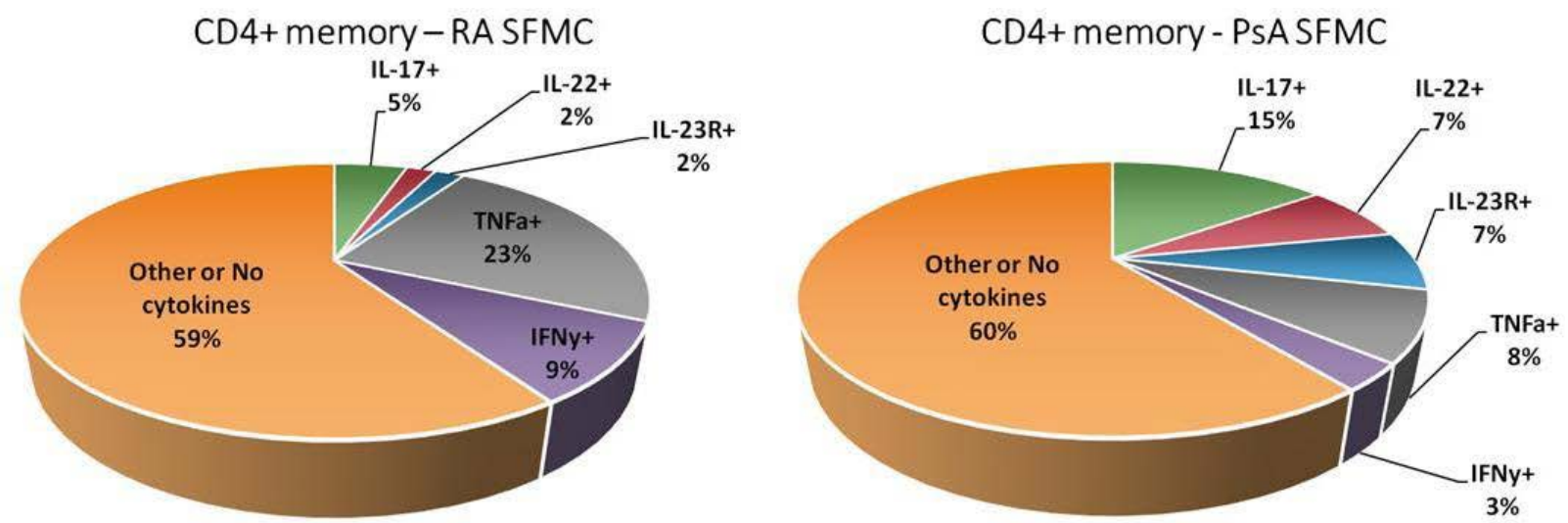

Figure 1 Polyfunctional synovial fluid effector memory T cells and its variations in RA and PsA. 10\%/mL SFMCs were incubated for 6 days in 24 -well plates precoated with $5 \mu \mathrm{g} / \mathrm{mL}$ anti-CD3 (UCHT1, eBioscience) and $2 \mu \mathrm{g} / \mathrm{mL}$ soluble anti-CD28 (CD28.2, eBioscience) antibodies. On day 6, cells were activated with PMA $(50 \mathrm{ng} / \mathrm{mL})$ and ionomycin $(1 \mathrm{ug} / \mathrm{mL})$; and for intracellular staining, Monensin was added to the cell culture ( $2 \mu \mathrm{M}$, Sigma). FlowJo software was used to gate and analyse the $\mathrm{CD}^{+} \mathrm{CD} 4^{+} \mathrm{CD} 11 \mathrm{a}^{+} \mathrm{CD} 45 \mathrm{RO}^{+}$cells. This figure is adapted from original publication by Raychaudhuri et al. ${ }^{5}$ PsA, psoriatic arthritis; RA, rheumatoid arthritis; SFMC, synovial fluid mononuclear cells. 
are skewed more towards the Th17 cells when compared with RA. At different time points of a disease process, it is expected that the kinetics of the polyfunctionality of these cells along with their cytokine profile would vary. Thus, this could be a possible explanation for treatment failure or variations in responsiveness to a specific anticytokine therapeutic agent in a patient with RA or in a patient with PsA.

\section{Smriti K Raychaudhuri, ${ }^{1}$ Christine Abria, ${ }^{2}$ Siba P Raychaudhuri $\odot^{3}$}

${ }^{1}$ School of Medicine, University of California Davis/Sacramento VA Medical Center, Davis, California, USA

${ }^{2}$ Rheumatology, Sacramento VA Medical Center, Mather, California, USA

${ }^{3}$ Division of Rheumatology, Allergy and Clinical Immunology/ Sacramento VA Medical Center, School of Medicine University of California, Davis, California, USA

Correspondence to Dr Siba P Raychaudhuri, Division of Rheumatology, Allergy and Clinical Immunology, University of California, Davis, CA 95616, USA; sraychaudhuri@ucdavis.edu

Contributors SKR participated in designing the study, lab experiments, data analysis and manuscript preparation. CA participated in designing the study, lab experiments, data analysis and manuscript preparation. CPR participated in designing the study, data analysis and manuscript preparation.

Funding This project was supported by the VA Medical Center Sacramento.

Disclaimer Contents do not necessarily represent the views of the Department of Veterans Affairs or the United States Government.

Competing interests None declared.

Patient consent for publication Not required.
Provenance and peer review Not commissioned; internally peer reviewed.

(C) Author(s) (or their employer(s)) 2019. No commercial re-use. See rights and permissions. Published by BMJ.

A) Check for updates

To cite Raychaudhuri SK, Abria C, Raychaudhuri SP. Ann Rheum Dis Epub ahead of print: [please include Day Month Year]. doi:10.1136/annrheumdis-2019-216658

Received 17 November 2019

Accepted 11 December 2019

Ann Rheum Dis 2019;0:1-2. doi:10.1136/annrheumdis-2019-216658

ORCID iD

Siba P Raychaudhuri http://orcid.org/0000-0001-7594-6528

\section{REFERENCES}

1 Wade SM, Canavan M, McGarry T, et al. Association of synovial tissue polyfunctional T-cells with DAPSA in psoriatic arthritis. Ann Rheum Dis 2019;78:350-4.

2 Raychaudhuri SK, Abria C, Mitra A, et al. Functional significance of MAIT cells in psoriatic arthritis. Cytokine 2020;125:154855.

3 Raychaudhuri SK, Abria C, Raychaudhuri SP. Functional significance of interleukin-9 and its receptor system in the pathogenesis of psoriatic arthritis: Comment on the article by Ciccia et al. Arthritis Rheumatol 2017;69:472-3.

4 Raychaudhuri SP, Raychaudhuri SK, Genovese MC. IL-17 receptor and its functional significance in psoriatic arthritis. Mol Cell Biochem 2012;359:419-29.

5 Raychaudhuri S, Raychaudhuri S. Diversity of Poly-Functional T Cells in Psoriatic Arthritis and Rheumatoid Arthritis and Its Therapeutic Significance [abstract]. Arthritis Rheumatol 2019;71. 